\title{
Bone mineral density in young women of the city of São Paulo, Brazil: correlation with both collagen type I alpha 1 gene polymorphism and clinical aspects
}

\footnotetext{
E.R. Barros ${ }^{1}$,

T.S. Kasamatsu2,

A.C. Ramalho ${ }^{3}$,

O.M. Hauache2,

J.G.H. Vieira ${ }^{1}$ and

M. Lazaretti-Castro ${ }^{1}$
}

\author{
${ }^{1}$ Setor de D oença Ó steo-Metabólica, and \\ 'Laboratório de Endocrinologia Molecular, Disciplina de Endocrinologia, \\ Universidade Federal de São Paulo, São Paulo, SP, Brasil \\ ${ }^{3}$ Faculdade Baiana de Medicina e Saúde Pública, Salvador, BA, Brasil
}

\section{Correspondence}

\section{Lazaretti-Castro}

Caixa Postal 20266

Vila Clementino

04034-970 São Paulo, SP

\section{Brasi}

E-mail: mlazaretti@endocrino.epm.br

Research supported by CN Pq. Publication supported by FAPESP.

Received November 28, 2001 Accepted May 24, 2002

\section{Abstract}

Osteoporosis is a multifactorial disease with great impact on morbidity and mortality mainly in postmenopausal women. Although it is recognized that factors related to life-style and habits may influence bone mass formation leading to greater or lower bone mass, more than $85 \%$ of the variation in bone mineral density (BMD) is genetically determined. The collagen type I alpha 1 (COLIA1) gene is a possible risk factor for osteoporosis. We studied a population of 220 young women from the city of São Paulo, Brazil, with respect to BMD and its correlation with both COLIA1 genotype and clinical aspects. The distribution of COLIA1 genotype SS, Ss and ss in the population studied was $73.6,24.1$ and $2.3 \%$, respectively. No association between these genotypes and femoral or lumbar spine BMD was detected. There was a positive association between lumbar spine BMD and weight $(\mathrm{P}<0.0001)$, height $(\mathrm{P}<0.0156)$, and body mass index (BMI) $(\mathrm{P}<0.0156)$, and a negative association with age at menarche $(\mathrm{P}<0.0026)$. There was also a positive association between femoral BMD and weight $(\mathrm{P}<0.0001)$, height $(\mathrm{P}<0.0001)$, and $\mathrm{BMI}(\mathrm{P}<0.0001)$, and a negative correlation with family history for osteoporosis $(\mathrm{P}<0.041)$. There was no association between the presence of allele $\mathrm{s}$ and reduced BMD. We conclude that a family history of osteoporosis and age at menarche are factors that may influence bone mass in our population.

\section{Introduction}

Osteoporosis is a common disease that affects $30 \%$ of women and $12 \%$ of men at some time in their lives (1). It is characterized by reduced bone mineral density (BMD) and deterioration of the microarchitecture of bone
Key words - COLIA1

- Bone mineral density

- Risk factors

- Polymorphism

- O steoporosis tissue, leading to increased fragility and greater risk of fracture (2). With the increase in life expectancy among western human populations, osteoporosis is becoming one of the major public health problems, with great impact on morbidity and mortality among elderly people. A reduction of one standard deviation (SD) in 
BMD increases the risk of osteoporotic fractures by 2.4 at different skeletal sites (3). BMD is the best known predictor for the risk of osteoporotic fractures. Both genetic and environmental factors influence BMD. Therefore, osteoporosis is considered a multifactorial disorder.

Initial evidence of the influence of genetic factors on bone mass was reported by Smith et al. (4), who found a greater concordance between forearm BMD in monozygotic twins as compared with dizygotic twins. Family studies and twin studies have shown that $75-85 \%$ of BMD is under genetic control (4-9). Due to the heterogeneity of its presentation, osteoporosis should be considered a polygenic disease. Within this context, several genes have been investigated, including those that encode the vitamin D receptor (10-12), the estrogen receptor $(10,12,13)$, transforming growth factor- $\beta$ $(10,14)$, interleukin-6 $(10,14)$, the calcitonin receptor (15), and collagen type I alpha 1 (COLIA1) (10,12-16).

Recently, several workers described a strong association between COLIA1 gene polymorphism and the occurrence of osteoporotic fractures. Collagen is the most abundant protein in bone, type 1 being the most frequent. It is constituted by two alpha 1 chains and one alpha 2 chain. These chains have a similar spatial structure and are encoded by distinct genes located on chromosomes 17 and 7, respectively. Since several mutations of the collagen type 1 gene have been described in patients with osteogenesis imperfecta, this gene has been considered a strong candidate for the genetic regulation of bone mass (17-19). Grant et al. (16) described a polymorphism at a recognition site for the transcription factor Sp1 in the COLIA1 gene, and found a greater expression of allele "s" in patients with severe osteoporosis and vertebral fractures when compared with allele "S". Uitterlinder et al. (20), investigating 1778 postmenopausal Dutch women, found that those with the Ss genotype had
$2 \%$ lower BMD at the femoral neck and lumbar spine when compared with the SS group. Such reduction was even more marked in the ss group. Langdahl et al. (21) studied a population of Danish men and women with osteoporosis and found a 10-fold greater expression of genotype ss in patients with osteoporotic fractures as compared with the control group. This reflected a relative risk of 11.83 for osteoporotic vertebral fractures in individuals with genotype ss. Those findings suggest that COLIA1 gene polymorphism is associated with reduced bone mass and increased risk of fractures, although negative results have been reported (2224).

In Brazil, data on BMD and its relations to genetic and environmental factors in a population are rare and knowledge of such characteristics is of fundamental importance for a better understanding of osteometabolic diseases and the elaboration of effective strategies for disease prevention and treatment.

On the basis of the multifactorial behavior of osteoporosis, the objective of the present study was to measure BMD in a population of young eumenorrheic women from São Paulo city and to correlate the data with both genetic (COLIA1 gene polymorphism) and clinical aspects.

\section{Material and Methods}

This study was approved by the Medical Ethics Committee and written consent was obtained from each subject.

\section{Subjects}

Our surveyed population consisted of 220 healthy and eumenorrheic female volunteers (mean age: $32.6 \pm 5.8$ years, range: 20 to 46 ), who lived in the city of São Paulo and were either staff members or students in the public health area, classified according to self-reported race $(70.9 \%$ white, $5.3 \%$ black, $6.9 \%$ oriental and 16.6\% mixed origin - Cauca- 
sian/black). Our exclusion criteria were: presence of amenorrhea, a history of disease or use of drugs that might interfere with bone metabolism.

\section{Method}

Of the 220 volunteers, 195 answered a questionnaire about personal data (age at menarche, history of fractures, familial antecedents for osteoporosis, use of contraceptives, current calcium intake, pregnancies, lactation, schooling), habits (alcohol and coffee intake, smoking, physical activity) and also anthropometric features (weight, height and body mass index, BMI).

A food inquiry intended to gather data on consumption of dairy products was conducted. On the basis of ingestion of dairy calcium, the subjects were divided into three groups: less than $500 \mathrm{mg}$ /day, between 500 and 1000 $\mathrm{mg}$ /day, and more than $1000 \mathrm{mg} /$ day. Alcohol intake was considered present when a minimum of one dose $(50 \mathrm{ml} / 50 \mathrm{~g})$ of spirits or $200 \mathrm{ml}$ of fermented drink was consumed daily. Smoking was considered present when a minimum of 54 packs of cigarettes were smoked yearly. The limits described above were determined according to the lowest consumption informed by a patient who selfreported to be a smoker or an alcohol consumer.

BMD was determined by dual energy Xray absorptiometry (Lunar DPX-L) at the lumbar spine (L2-L4) and femoral neck. The lumbar spine and femoral BMD of white women $(\mathrm{N}=132)$ were analyzed separately and by age range (10-year intervals) to compare with BMD values from the data bank of a DPX-Lunar densitometer concerning American and European white women (UK and Scandinavia) (25) and with BMD values for white Brazilian women from another study (26).

\section{Collagen type 1 polymorphism}

Genomic DNA was extracted from leu- kocytes of peripheral blood samples of the 220 subjects using a commercial kit (Puregene DNA Isolation kits, Gentra Systems, Inc., Minneapolis, MN, USA).

The $\mathrm{G} \rightarrow$ T polymorphism at the Sp1 binding site of the COLIA1 gene was analyzed according to the method described by Langdahl et al. (21). To perform the polymerase chain reaction (PCR), the primers 5'GTCCAGCCCTCATCCTGGCC-3' and 5'TAACTTCTGGACTATTTGCGGACTT TTTGG-3' were used (21). The final volume of PCR was $50 \mu \mathrm{l}$ containing $400 \mathrm{ng}$ of genomic DNA, 10 pmol of each primer, 1.5 $\mathrm{U}$ of Taq DNA polymerase, $0.2 \mathrm{mM}$ dNTPs, $1.5 \mathrm{mM} \mathrm{MgCl}_{2}$ and, 1X PCR buffer. PCR was performed under the following conditions: initial denaturation at $94^{\circ} \mathrm{C}$, followed by 35 cycles at $94^{\circ} \mathrm{C}$ for $1 \mathrm{~min}, 60^{\circ} \mathrm{C}$ for 1 $\min , 72^{\circ} \mathrm{C}$ for $1 \mathrm{~min}$, and a final extension at $72^{\circ} \mathrm{C}$ for 5 min using a PTC-200 thermocycler (Poltier Thermal Cycler, MJ Research Inc., Watertown, MA, USA). The final product was digested with $3 \mathrm{U}$ of the restriction enzyme BalI (Amersham Pharmacia Biotech, Little Chalfont, UK) overnight at $37^{\circ} \mathrm{C}$ (Techne DRL-Block BD-2D, Cambridge, UK). The digestion products were submitted to electrophoresis on $4 \%$ nuSieve GTG agarose gel (FMC BioProducts, Rockland, ME, USA), treated with ethidium bromide ( 0.5 $\mu \mathrm{g} / \mathrm{ml}$ ) and analyzed under ultraviolet light. The PCR product containing allele $\mathrm{s}$ is cleaved by the enzyme BalI, which identifies the $\mathrm{G} \rightarrow \mathrm{T}$ substitution, resulting in a band of 246 bp compared with the non-cleaved $S$ allele, with a band of 264 bp (Figure 1).

\section{Statistical analysis}

The data are presented as means $\pm \mathrm{SD}$. Comparisons of BMD and the other variables were made by the Student $t$-test and chi-square test when appropriate. The Bonferroni $t$-test was used for multiple comparisons of BMD among ethnic groups. The level of significance was set at $\mathrm{P}<0.05$. 


\section{Results}

\section{Distribution of findings in the group studied}

Data on age, anthropometric measurements, lumbar spine and femoral BMD and

Figure 1. Digestion products of the collagen type I alpha 1 gene with Bal1. SS = homozygote normal; $\mathrm{M}=$ molecular size marker.

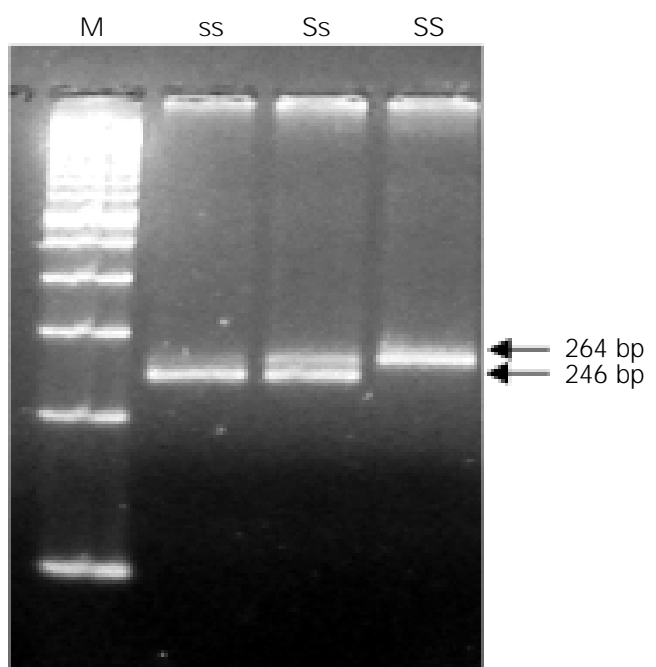

Table 1. Age, age at menarche, anthropometric data and bone mineral density (BMD) of the population studied.

\begin{tabular}{lllc}
\hline Variable & $\mathrm{N}$ & Mean $\pm \mathrm{SD}$ & Range \\
\hline Age (years) & 220 & $32.6 \pm 5.8$ & $20-46$ \\
Menarche (years) & 185 & $12.5 \pm 1.6$ & $9-17$ \\
Weight $(\mathrm{kg})$ & 195 & $61.7 \pm 11.3$ & $39-96$ \\
Height $(\mathrm{m})$ & 195 & $1.58 \pm 0.1$ & $1.44-1.85$ \\
BMI $\left(\mathrm{kg} / \mathrm{m}^{2}\right)$ & 195 & $24.4 \pm 4.2$ & $18-40$ \\
BMD L2-L4 $\left(\mathrm{g} / \mathrm{cm}^{2}\right)$ & 195 & $1.19 \pm 0.14$ & $0.75-1.63$ \\
BMD femoral $\left(\mathrm{g} / \mathrm{cm}^{2}\right)$ & 195 & $0.97 \pm 0.12$ & $0.66-1.53$ \\
\hline
\end{tabular}

$\mathrm{BMI}=$ body mass index. age at menarche are presented in Table 1.

The mean values for lumbar spine and femoral BMD of the white women studied $(\mathrm{N}=132)$, divided into three distinct age groups, are presented in Table 2 . In the three groups, both femoral neck and lumbar spine BMD values were similar and did not change with age. Comparison of the present younger age group (20 to 29 years old) with similar data from other studies showed that the average spine and femoral neck BMD was lower than for the population studied by the manufacturer (25), consisting of Caucasian American and European women.

The comparison of our population with another population of white Brazilian women published by others (26) showed that our subjects presented higher lumbar spine BMD in the 40- to 49-year age range and higher femoral neck BMD in the 30- to 39-year age range (Table 2).

\section{Correlation between BMD and the other variables analyzed}

Age and anthropometric measurements (weight, height and BMI). Among the various parameters measured, body weight correlated most strongly with lumbar spine BMD $(\mathrm{r}=0.46, \mathrm{P}<0.001)$ and femoral BMD $(\mathrm{r}=$ $0.49, \mathrm{P}<0.001)$. A statistically significant correlation was also found between height and both spinal $(\mathrm{r}=0.17, \mathrm{P}<0.015)$ and femoral neck BMD $(\mathrm{r}=0.34, \mathrm{P}<0.001)$, and

Table 2. Bone mineral density (BMD) data of the white women from this and other studies

\begin{tabular}{|c|c|c|c|c|c|c|c|c|c|}
\hline \multirow[t]{2}{*}{ Age (years) } & \multicolumn{3}{|c|}{ Study population } & \multicolumn{3}{|c|}{ USA/Europe (Ref. 25) } & \multicolumn{3}{|c|}{ Other Brazilian study (Ref. 26) } \\
\hline & $\mathrm{N}$ & Femoral & L2-L4 & N (femoral/ L2-L4) & Femoral & L2-L4 & $\mathrm{N}$ & Femoral & L2-L4 \\
\hline $20-29$ & 40 & $0.956 \pm 0.09^{+}$ & $1.160 \pm 0.12^{\#}$ & $739 / 672$ & $0.998 \pm 0.12$ & $1.200 \pm 0.12$ & 27 & $0.950 \pm 0.12$ & $1.180 \pm 0.14$ \\
\hline $30-39$ & 77 & $0.965 \pm 0.12^{*}$ & $1.200 \pm 0.14$ & $1067 / 916$ & $0.973 \pm 0.12$ & $1.210 \pm 0.12$ & 47 & $0.890 \pm 0.08$ & $1.170 \pm 0.11$ \\
\hline $40-49$ & 15 & $1.185 \pm 0.15^{+}$ & $1.190 \pm 0.15$ & $1746 / 1630$ & $0.946 \pm 0.12$ & $1.180 \pm 0.12$ & 126 & $0.890 \pm 0.09$ & $1.140 \pm 0.12$ \\
\hline Total & 132 & & & $3552 / 3218$ & & & 200 & & \\
\hline
\end{tabular}

Data are reported as means $\pm S D\left(g / \mathrm{cm}^{2}\right)$.

$+P<0.05$ between femoral neck BMD of the population studied and American and European women;

$* \mathrm{P}<0.05$ between femoral neck BMD of the population studied and Brazilian women;

$\#$ P $<0.05$ between lumbar spine BMD of the population studied and American and European women (one-way Bonferroni t-test). 
between BMI and both spinal $(r=0.41$, $\mathrm{P}<0.001)$ and femoral neck BMD $(\mathrm{r}=0.36$, $\mathrm{P}<0.001$ ).

Schooling. In our study group, 91 (49\%) of the women had completed college, a feature closely related to the socioeconomic status of this population. However, no significant differences in lumbar spine or femoral BMD were found between the women with higher education and the remaining group of the population.

Menarche, reproductive history, lactation and use of contraceptives. Age at menarche was negatively correlated with lumbar spine BMD ( $\mathrm{r}=-0.22, \mathrm{P}<0.002)$ but showed no association with femoral BMD. Ninety-nine subjects (53\%) of our population reported at least one episode of pregnancy; of these, 85 (85\%) breastfed their child for at least 3 months in at least one pregnancy. Femoral and spinal BMD did not differ between women with a positive history of pregnancy or lactation and subjects with no such history. One hundred and eighteen $(58 \%)$ women were using or had used oral contraceptives for at least one year in their lives. No association was found between previous or current use of oral contraceptives and BMD at the sites analyzed.

Previous fractures and family history of osteoporosis. Thirty-nine (21\%) women had a history of previous fractures, all of them related to trauma and $39(21 \%)$ had a family history of osteoporosis. Femoral BMD (0.93 $\left.\pm 0.11 \mathrm{~g} / \mathrm{cm}^{2}\right)$ in the group with a positive family history was significantly lower than in the group with no family history $(0.98 \pm$ $\left.0.11 \mathrm{~g} / \mathrm{cm}^{2}, \mathrm{P}<0.041\right)$ and the difference remained significant even after correction for weight and height (data not shown). Lumbar spine BMD was not influenced by the presence or absence of a family history of osteoporosis. No association was found between personal history of previous fractures and lumbar spine or femoral BMD.

Calcium intake. The inquiry on consumption of dairy products revealed that $80(41 \%)$ women consumed less than $500 \mathrm{mg} /$ day, 90 (49.7\%) 500 to $1000 \mathrm{mg} /$ day and only 15 $(8.3 \%)$ more than $1000 \mathrm{mg} /$ day. Spine BMD did not differ between these three groups $(1.20 \pm 0.12,1.19 \pm 0.16$ and $1.13 \pm 0.13$ $\mathrm{g} / \mathrm{cm}^{2}$, respectively). A similar finding was observed regarding femoral BMD (corresponding BMD values: $0.98 \pm 0.13,0.97 \pm$ 0.12 and $0.95 \pm 0.13 \mathrm{~g} / \mathrm{cm}^{2}$ ).

Physical activity. Previous physical exercise on a regular basis and at least twice a week was reported by 107 (58\%) subjects, only 7 of whom were engaged in competitive activities. Only $33(17.7 \%)$ of the women were practicing some kind of physical exercise at the time of the study. However, no association was found between femoral or lumbar spine BMD values and previous or current physical activity.

Habits (alcohol and coffee consumption and smoking). Alcohol intake was found to be rare in the population studied; no woman reported consuming spirits and only 29 (15.7\%) reported sporadic ingestion of fermented drinks (maximum of one drink once a week). One hundred and fifty-five (84.4\%) women denied drinking any alcoholic beverage. The femoral and lumbar spine BMD of these women did not differ from women who reported alcohol intake. Ingestion of at least six cups of coffee a day $(300 \mathrm{ml}$ of coffee) was reported by $56(30.1 \%)$ women; smoking more than three cigarettes/day was reported by 48 (25.8\%). No association was found between drinking coffee or smoking and lumbar spine or femoral BMD.

Ethnic group. Race distribution was as follows: white (70.9\%), black (5.3\%), oriental $(6.9 \%)$ and mixed racial origin (Caucasian/black) (16.6\%). Black subjects presented higher femoral and spinal BMD compared to the other ethnic groups (Table 3 ).

\section{COLIA1 gene polymorphism}

The study of polymorphism at the transcription factor $\mathrm{Sp} 1$ binding site of the 
COLIA1 gene indicated that the SS genotype was found in $162(73.6 \%)$ of the 220 subjects, Ss in $53(24.09 \%)$ and ss in only 5 $(2.27 \%)$. The Ss and ss groups were analyzed together due to the small number of individuals in the ss group. Both the SS and

Table 3. Lumbar spine and femoral neck bone mineral density (BMD) of the population studied according to racial distribution.

\begin{tabular}{lll}
\hline Race & \multicolumn{1}{c}{ L2-L4 } & \multicolumn{1}{c}{ Femoral } \\
\hline White $(\mathrm{N}=132)$ & $1.18 \pm 0.14^{*}$ & $0.96 \pm 0.11^{* *}$ \\
Black $(\mathrm{N}=10)$ & $1.32 \pm 0.13^{*}$ & $1.11 \pm 0.20^{* *+}$ \\
Oriental $(\mathrm{N}=13)$ & $1.22 \pm 0.16$ & $0.94 \pm 0.09^{+}$ \\
Mixed $(\mathrm{N}=31)$ & $1.18 \pm 0.14$ & $1.00 \pm 0.12$ \\
\hline
\end{tabular}

Data are reported as means $\pm \mathrm{SD}\left(\mathrm{g} / \mathrm{cm}^{2}\right)$.

$* \mathrm{P}<0.05$ for lumbar spine BMD between the white and black women; $* * P<0.05$ for femoral neck BMD between the white and black women; $+P<0.05$ for femoral neck BMD between the oriental and black women (one-way Bonferroni t-test).

Table 4. Racial distribution and bone mineral density (BMD) according to collagen type I alpha 1 genotype.

\begin{tabular}{|c|c|c|c|c|c|c|c|}
\hline \multirow[t]{2}{*}{ Race } & \multicolumn{3}{|c|}{ SS } & \multicolumn{3}{|c|}{ Ss/ss } & \multirow[t]{2}{*}{ Total } \\
\hline & $\mathrm{N}$ & L2-L4 & Femoral & $\mathrm{N}$ & L2-L4 & Femoral & \\
\hline White & 94 & $1.18 \pm 0.14$ & $0.95 \pm 0.12$ & 38 & $1.19 \pm 0.15$ & $0.97 \pm 0.10$ & 132 \\
\hline Black & 10 & $1.32 \pm 0.20$ & $1.11 \pm 0.20$ & 0 & & & 10 \\
\hline Oriental & 12 & $1.23 \pm 0.17$ & $0.95 \pm 0.90$ & 1 & 1.14 & 0.90 & 13 \\
\hline Mixed & 23 & $1.12 \pm 0.13$ & $1.02 \pm 0.11$ & 8 & $1.13 \pm 0.21$ & $0.94 \pm 0.15$ & 31 \\
\hline
\end{tabular}

Data are reported as means $\pm \mathrm{SD}\left(\mathrm{g} / \mathrm{cm}^{2}\right)$. Chi-square of Pearson $=6.25, \mathrm{r}=0.0100$.

Table 5. Age, age at menarche, anthropometric data and bone mineral density (BMD) according to collagen type I alpha 1 genotype.

\begin{tabular}{lccc}
\hline Variable & \multicolumn{2}{c}{ Genotype } & P \\
\cline { 2 - 3 } & \multicolumn{2}{c}{ SS } & Ss/ss \\
\hline Age (years) & $32.7 \pm 6.13$ & $32.3 \pm 5.11$ & 0.6301 \\
Menarche (years) & $12.5 \pm 1.64$ & $12.7 \pm 1.47$ & 0.3950 \\
Height (m) & $1.59 \pm 0.06$ & $1.60 \pm 0.07$ & 0.2698 \\
Weight $(\mathrm{kg})$ & $62.2 \pm 11.6$ & $60.5 \pm 10.3$ & 0.3607 \\
BMI (kg/m 2$)$ & $24.7 \pm 4.37$ & $23.6 \pm 3.42$ & 0.1077 \\
BMD L2-L4 (g/cm $\left.{ }^{2}\right)$ & $1.20 \pm 0.14$ & $1.18 \pm 0.158$ & 0.5069 \\
BMD femoral $\left(\mathrm{g} / \mathrm{cm}^{2}\right)$ & $0.98 \pm 0.13$ & $0.96 \pm 0.12$ & 0.4126
\end{tabular}

Data are reported as means $\pm \mathrm{SD}$. BMI = body mass index.
Ss/ss groups showed similar clinical features, except for ethnic distribution. The ethnic group distribution and spinal and femoral BMD are presented in Table 4 . The presence of allele s was rare among (2/13) oriental women and absent among black women.

No significant differences were found regarding BMD, age, body weight, height, BMI or age at menarche (Table 5).

\section{Discussion}

The contribution of genetic factors to bone mass is well documented. However, it is not possible to ignore the interaction between heredity and both environmental and life-style factors when studying determinants of BMD. We first attempted to study the association between vitamin $D$ receptor polymorphism and BMD in a similar population. Lazaretti-Castro et al. (27) investigated vitamin D receptor gene polymorphism and BMD in a population of young women from the city of São Paulo and detected lower spinal and femoral BMD in subjects with the BB genotype when compared with the bb genotype.

Recent studies $(16,20)$ found an association between polymorphism for the binding site of transcription factor $\mathrm{Sp} 1$ in the first intron of the COLIA1 gene and BMD in two different populations, making this gene a candidate for osteoporotic risk factor. In the population studied here, the distribution of genotypes of the Sp1 binding site polymorphism in the COLIA1 gene showed a predominance of the SS genotype (73.6\%) compared with Ss $(24.1 \%)$ and ss $(2.3 \%)$. This predominance has also been reported in the literature (20-23).

We found no association between Sp1 binding site polymorphism and spine BMD or femur BMD. A similar finding was also described by Heegaard et al. (22), who reported no association between COLIA1 gene polymorphism and BMD in postmenopausal Danish women. Similarly, Berg et al. (23) 
did not detect a correlation between COLIA1 gene polymorphism and BMD in healthy children, adolescents and young adults. Similar results were described by Lidén et al. (24) who analyzed this association in Swiss postmenopausal women. Despite these negative findings, this type of polymorphism deserves our attention since in a recent meta-analysis (13 studies including 3641 participants) Efstathiadou et al. (28) demonstrated a positive association between COLIA1 gene polymorphism and the risk of vertebral fracture. Group Ss risk was 1.25 times higher than that of group SS, group ss risk was 1.68 times higher when compared to group SS, and group ss risk was 1.35 times higher than group Ss. It should be noted that most of the populations studied in this meta-analysis were older than ours. Nevertheless, Hustmyer et al. (29), studying young American female twins, also found no correlation between BMD and COLIA1 gene polymorphism. These data, taken together, suggest that the COLIA1 genotypes are not related to peak bone mass but may play a role in the rate of bone loss during the aging process.

Our population was quite heterogeneous with respect to distribution of ethnic groups, a feature that reflects the historical heterogeneity and miscegenation of Brazilian populations. Our black women $(\mathrm{N}=10)$ exclusively expressed the SS genotype and had a higher BMD when compared to the other ethnic groups, irrespective of their genotype. This finding should be viewed with caution, since the number of black women in our population was small. The BMD of our mixed ethnic group did not differ significantly from that of the white women. However, in Brazil we have to admit that it is not easy to classify individuals according to ethnic origin. Since the majority of women in this group have white and black ancestors, it might be possible to hypothesize that the bone protection conferred by black ethnic origin may be lost after miscegenation with whites. The spine BMD of our white women differed from that of the white Brazilian women studied by Szejnfeld et al. (26) in the 40- to 49-year age range; additionally, we also found a significant difference in femoral BMD between these two populations in the 30- to 39-year age group.

An important finding was the fact that white women 20-29 years of age presented significantly lower spinal and femoral BMD than age-matched white American and European women (25). This difference has great importance since most of the DEXA devices used in Brazil consider as reference normal range the European and American populations. Furthermore, although we defined one of our groups as composed of white women, it should be stressed again that we face some difficulty in establishing the exact ethnic profile of local populations. Additionally, we should also take into account the fact that the maximum age of the population included in this study was 46 years and that our 40 - to 46-year age range group was compared with populations within the 40- to 49-year age range. This may possibly explain the higher values of lumbar spine BMD found in our population compared with those reported by Szejnfeld et al. (26).

We found a positive correlation between spinal and femoral BMD and body weight, height and BMI. This is in accordance with Bauer et al. (30), who found body weight to be a strong predictor of high bone mass. Interestingly, we also detected an association between a family history of osteoporosis and reduced femoral BMD, as also reported by Bauer et al. (30) and Cummings et al. (31), who found lower bone mass values in patients with a maternal history of vertebral fractures, forearm fractures or osteoporosis. Age at menarche was found to be negatively correlated with lumbar spine BMD, an association suggested by Sowers et al. (32) and Rosenthal et al. (33).

We found no correlation between BMD and the other variables studied, such as reported calcium and alcohol intake, smoking, 
physical activity, use of contraceptives, lactation and pregnancy. The literature on these parameters is controversial. However, our data support the findings of Bauer et al. (30) and Mazess and Barden (34), who likewise did not find an association between BMD and the variables described above. A similar contradictory picture is found in the literature with respect to ingestion of alcohol and BMD. The Framingham Study (35) reports a positive correlation between ingestion of alcoholic drinks and BMD. Conversely, Bauer et al. (30) and the current study found no association. With respect to coffee, our data support the findings by Lloyd et al. (36), who reported no correlation between drinking coffee and BMD in a group of young American adolescents.

Our data indicate that COLIA1 gene polymorphism is not a good predictor for reduced BMD, and that parameters like body weight, height, age at menarche and a family history of osteoporosis may contribute as risk factors for reduced BMD in the population studied here.

\section{References}

1. Kanis J A, Melton III J R, Christiansen C, J ohnston CC \& Khaltaev N (1994). The diagnosis of osteoporosis. J ournal of Bone and Mineral Research, 9: 11371141.

2. Cummings SR, Black DM, Nevitt MC, Browner WS, Cauley JA, Genant HK, Mascioli SR, Scott J C, Seeley DG, Steiger P \& Vogt TM (1990). Appendicular bone density and age predict hip fracture in women. J ournal of the American Medical Association, 263: 665-668.

3. Cummings SR, Black DM, Nevitt MC, Browner W, Cauley J, Ensrud K, Genant HK, Palermo L, Scott J \& Vogt TM (1993). Bone density at various sites for prediction of hip fractures. Lancet, 341: 72-75.

4. Smith DM, Nance WE, Kang KW, Christian J C \& J ohnston J r CC (1973). Genetic factors in determining bone mass. J ournal of Clinical Investigation, 52: 28002808.

5. Pocock NA, Eisman J A, Hopper J L, Yeates MG, Sambrook PN \& Eberl S (1987). Genetic determinants of bone mass in adults. J ournal of Clinical Investigation, 80: 706-710.

6. Christian JC, Yu PL, Slemenda CW \& J ohnston J r CC (1989). Heritability of bone mass: a longitudinal study in aging male twins. American J oumal of Human Genetics, 44: 429-433.

7. Kelly PJ , Nguyen T, Hopper J, Pocock N, Sambrook P \& Eisman J (1993). Changes in axial bone density with age: $A$ twin study. J ournal of Bone and Mineral Research, 8: 11-17.

8. Tylavsky FA, Bertz AD, Hancock RL \& Anderson JJ (1989). Familial resemblance of radial bone mass between premenopausal mothers and their college-age daughters. Calcified Tissue Intemational, 45: 265-272.

9. Krall EA \& Dawson-Hughes B (1993). Heritable and life-style determinants of BMD. J oumal of Bone and Mineral Research, 8: 1-9.

10. Hobson EE \& Ralston SH (1997). The genetics of osteoporosis. Endocrinologist, 7: 429-435.

11. Morrison NA, Yeoman R, Kelly PJ \& Eisman J A (1992). Contribution of transacting factor alleles to normal physiological variability: vitamin $D$ receptor gene polymorphisms and circulating osteocalcin. Proceedings of the National Academy of Sciences, USA, 89: 6665-6669.

12. Aerssens J, Dequeker J, Peeters J, Breemans S, Broos P \& Boonen S (2000). Polymorphisms of the VRD, ER and COLIA1 genes and osteoporotic hip fracture in elderly postmenopausal women. Osteoporosis Intemational, 11: 583-591.

13. Kobayashi $\mathrm{S}$, Inoue $\mathrm{S}$, Hosoi $\mathrm{T}$, Ouchi $\mathrm{Y}$, Shiraki M \& Orimo H (1996). Association of BMD with polymorphism of the estrogen receptor gene. J ournal of Bone and Mineral Research, 11: 306-311.

14. Ralston SH (1997). Genetic markers of bone metabolism and bone disease. Scandinavian J ournal of Clinical and Laboratory Investigation, 57 (Suppl 227): 114-121.

15. Braga V, Mottes M, Mirandola S, Lisi V, Malerba G, Sartori L, Bianchi G, Gatti D, Rossini M, Bianchini D \& Adami S (2000). Association of CTR and COLIA1 alleles with BMD values in peri- and postmenopausal women. Calcified Tissue International, 67: 361-366.

16. Grant SFA, Reid DM, Blake G, Herd R, Fogelman I \& Ralston SH (1996). Reduced bone density and osteoporosis associated with a polymorphic Sp1 binding site in the collagen type I $\alpha 1$ gene. Nature Genetics, 14: 203-205.

17. Nuytinck $L$, Dalgleish $R$, Spotila $L$, Renard J P, Regemorter NV \& De Paepe A (1996). Substitution of glycine-661 by serine in the $\alpha 1(I)$ and $\alpha 2(I)$ chains of type I collagen results in different clinical and biochemical phenotypes. Human Genetics, 97: 324-329.

18. Spotila LD, Colige A, Sereda L, Constantinou-Deltas CD, Whyte MP, Riggs BL, Shaker J L, Spector TD, Hume E, Olsen N, Attie M, Tenenhouse A, Shane E, Briney W \& Prockop DJ (1994). Mutation analysis of coding sequences for type I procollagen in individuals with low bone density. J ournal of Bone and Mineral Research, 9: 923-932.

19. Willing $M C$, Deschenes SP, Scoot DA, Byers PH, Slayton RL, Pitts SH, Arikat H \& Roberts EJ (1994). Osteogenesis imperfecta type I: molecular heterogeneity for COLIA1 null alleles of type I collagen. American J ournal of Human Genetics, 55: 638-647.

20. Uitterlinder $A G$, Burger $H$, Huang $Q$, Yue F, McGuigan FEA, Grant SFA, Hofman A, Van Leeuwen J PTM, Pols HAP \& Ralston SH (1998). Relation of alleles of the collagen type I $\alpha 1$ gene to bone density and the risk of osteoporotic fractures in postmenopausal women. New England J ournal of Medicine, 338: 1016-1021.

21. Langdahl BL, Stuart H, Ralston H, Grant SFA \& Eriksen F (1998). An Spl binding site polymorphism in the COLIAl gene predicts osteoporotic fractures in both men and women. Journal of Bone and Mineral Research, 13: 1384-1389.

22. Heegaard AM, J orgensen HL, Vester- 
gaard AW, Hassager $\mathrm{C} \&$ Ralston $\mathrm{SH}$ (2000). Lack of influence of collagen type I $\alpha 1$ Spl binding site polymorphism on the rate of bone loss in a cohort of postmenopausal Danish women followed for 18 years. Calcified Tissue International, 66: 409-413.

23. Berg JP, Lehmann EH, Stakkestad J A, Haug E \& Halse J (2000). The Spl binding site polymorphism in the collagen type I $\alpha 1$ (COLIA1) gene is not associated with BMD in healthy children, adolescents, and young adults. European J oumal of Endocrinology, 143: 261-265.

24. Lidén $M$, Wilén $B$, Ljunghall $S \&$ Melhus $H$ (1998). Polymorphism at the Sp 1 binding site in the collagen type I $\alpha 1$ gene does not predict bone density in postmenopausal women in Sweden. Calcified Tissue International, 63: 293-295.

25. Lunar Corporate Headquarters (1998). Manual do operador DPX-IQ. Versão: 5/98 A, parte número: 6740 . Versão do software: 4.x. Madison, WI, USA.

26. Szejnfeld VL, Atra E, Baracat EC, Aldrighi J M \& Cevitelli R (1995). Bone density in white Brazilian women: rapid loss at the time around the menopause. Calcified Tis- sue International, 56: 186-191.

27. Lazaretti-Castro $M$, Duarte-de-Oliveira MA, Russo EMK \& Vieira J GH (1997). Vitamin $\mathrm{D}$ receptor alleles and BMD in a normal premenopausal Brazilian female population. Brazilian J ournal of Medical and Biological Research, 30: 929-932.

28. Efstathiadou Z, Tsatsoulis A \& Ioannidis J PA (2001). Association of collagen I $\alpha 1$ Spl polymorphism with the risk of prevalent fractures: a meta-analysis. J ournal of Bone and Mineral Research, 16: 15861592.

29. Hustmyer FG, Liu G, J ohnston CC, Christian J \& Peacock M (1999). Polymorphism at an Sp 1 binding site of COLIAl and BMD in premenopausal female twins and elderly fracture patients. Osteoporosis International, 9: 346-350.

30. Bauer DC, Browner WS, Cauley JA, Orwool ES, Scott J C, Black DM, Tao J o L \& Cummings SR (1993). Factors associated with appendicular bone mass in older women. Annals of Internal Medicine, 118: 657-665.

31. Cummings SR, Nevitt MC, Browner WS, Stone K, Fox KM, Ensrud KE, Cauley J, Black D \& Vogt TM (1995). Risk factors for hip fracture in white women. New England J oumal of Medicine, 332: 767-771.

32. Sowers $M R$, Clark MK, Hollis $B$, Wallace RB \& J annauschi M (1992). Radial BMD in pre- and perimenopausal women: A prospective study of rates and risk factors for loss. J ournal of Bone and Mineral Research, 7: 647-657.

33. Rosenthal DI, Mayo-Smith W, Hayes CW, Khurana J S, Biller BMK, Neer RM \& Klibanski A (1989). Age and bone mass in premenopausal women. J oumal of Bone and Mineral Research, 4: 533-538.

34. Mazess RB \& Barden H (1991). Bone density in premenopausal women: effects of age, dietary intake, physical activity, smoking, and birth-control pills. American J ournal of Clinical Nutrition, 53: 132-142.

35. Felson D, Zhang $Y$, Hannan MT, Kannel WB \& Kiel DP (1995). Alcohol intake and BMD in elderly men and women. The Framingham Study. American J ournal of Epidemiology, 142: 485-492.

36. Lloyd T, Rollings NJ , Kieselhorst K, Eggli DF \& Mauger E (1998). Dietary caffeine intake is not correlated with adolescent bone gain. J ournal of the American College of Nutrition, 17: 454-457. 


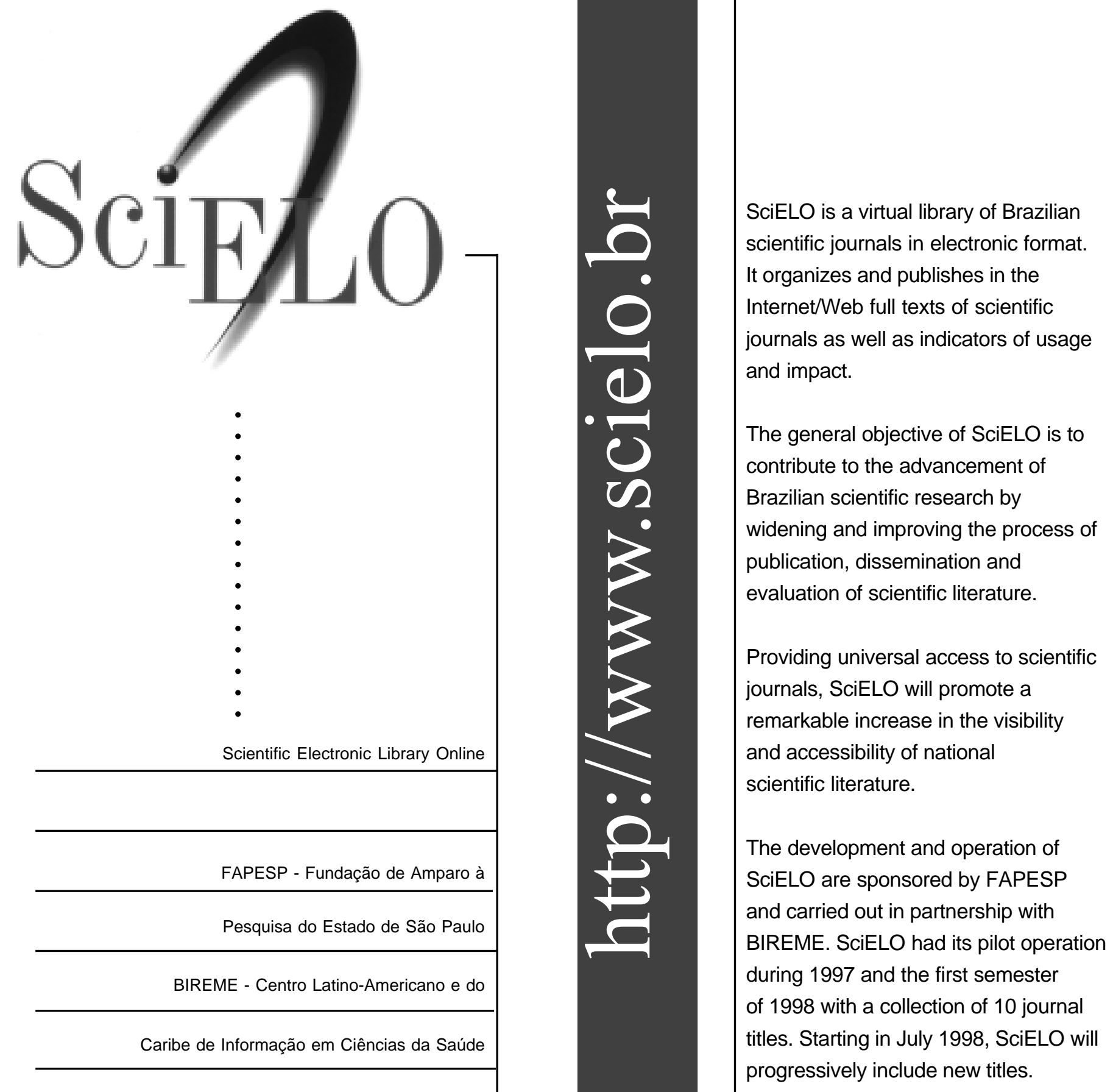

